\title{
Immunohistochemical Detection of Potential Microbial Antigens in Granulomas in the Diagnosis of Sarcoidosis
}

\author{
Tetsuo Yamaguchi ${ }^{1,2}{ }^{,}$Ulrich Costabel $^{3}$, Andrew McDowell $\left.{ }^{4}{ }^{(}\right)$, Josune Guzman ${ }^{5}$, Keisuke Uchida ${ }^{1}$, \\ Kenichi Ohashi ${ }^{1}$ and Yoshinobu Eishi ${ }^{1, *(1)}$ \\ 1 Department of Human Pathology, Graduate School and Faculty of Medicine, \\ Tokyo Medical and Dental University, Tokyo 113-8519, Japan; yamatet@icloud.com (T.Y.); \\ uchida.path@tmd.ac.jp (K.U.); kohashi.pth1@tmd.ac.jp (K.O.) \\ 2 Department of Pulmonology, Shinjuku Tsurukame Clinic, Tokyo 151-0053, Japan \\ 3 Department of Pneumology, Ruhrlandklinik, Medical Faculty, University of Duisburg-Essen, \\ 45239 Essen, Germany; Ulrich.Costabel@rlk.uk-essen.de \\ 4 Nutrition Innovation Centre for Food and Health (NICHE), School of Biomedical Sciences, \\ Ulster University, Coleraine BT52 1SA, UK; a.mcdowell@ulster.ac.uk \\ 5 Department of General and Experimental Pathology, Ruhr University, 44801 Bochum, Germany; \\ josune.guzman@rub.de \\ * Correspondence: eishi.path@tmd.ac.jp; Tel.: +81-90-3332-0948
}

check for

updates

Citation: Yamaguchi, T.; Costabel, U.; McDowell, A.; Guzman, J.; Uchida,

K.; Ohashi, K.; Eishi, Y.

Immunohistochemical Detection of

Potential Microbial Antigens in Granulomas in the Diagnosis of Sarcoidosis. J. Clin. Med. 2021, 10, 983. https://doi.org/10.3390/ jcm10050983

Academic Editor: Moritz Wildgruber

Received: 11 January 2021

Accepted: 23 February 2021

Published: 2 March 2021

Publisher's Note: MDPI stays neutral with regard to jurisdictional claims in published maps and institutional affiliations.

Copyright: (C) 2021 by the authors Licensee MDPI, Basel, Switzerland. This article is an open access article distributed under the terms and conditions of the Creative Commons Attribution (CC BY) license (https:/ / creativecommons.org/licenses/by/ $4.0 /)$.

\begin{abstract}
Sarcoidosis may have more than a single causative agent, including infectious and noninfectious agents. Among the potential infectious causes of sarcoidosis, Mycobacterium tuberculosis and Propionibacterium acnes are the most likely microorganisms. Potential latent infection by both microorganisms complicates the findings of molecular and immunologic studies. Immune responses to potential infectious agents of sarcoidosis should be considered together with the microorganisms detected in sarcoid granulomas, because immunologic reactivities to infectious agents reflect current and past infection, including latent infection unrelated to the cause of the granuloma formation. Histopathologic data more readily support P. acnes as a cause of sarcoidosis compared with $M$. tuberculosis, suggesting that normally symbiotic $P$. acnes leads to granuloma formation in some predisposed individuals with Th1 hypersensitivity against intracellular proliferation of latent $P$. acnes, which may be triggered by certain host or drug-induced conditions. Detection of bacterial nucleic acids in granulomas does not necessarily indicate co-localization of the bacterial proteins in the granulomas. In the histopathologic diagnosis of sarcoidosis, M. tuberculosis-associated and P. acnes-associated sarcoidosis will possibly be differentiated in some patients by immunohistochemistry with appropriate antibodies that specifically react with mycobacterial and propionibacterial antigens, respectively, for each etiology-based diagnosis and potential antimicrobial intervention against sarcoidosis.
\end{abstract}

Keywords: pathogenesis; quantitative PCR; hypersensitivity; immunohistochemistry; symbiosis; endogenous infection; Propionibacterium acnes; Corynebacterium parvum; Cutibacterium acnes; Mycobacterium tuberculosis

\section{Introduction}

Sarcoidosis is a systemic inflammatory disease that is characterized by the formation of noncaseating epithelioid cell granulomas at the sites of disease activity in multiple organs, including the lungs and lymph nodes [1]. Despite numerous studies using molecular and immunologic approaches, the cause of sarcoidosis remains uncertain. Sarcoidosis may have more than a single causative agent, including infectious and non-infectious agents [2]. Even if a specific microorganism is involved, the infectious agent does not need to cause sarcoidosis in every host or experimental animal according to Koch's postulates for establishing causation of an infectious disease [3].

Among the potential infectious agents, Mycobacterium tuberculosis and Propionibacterium acnes (formerly known as Corynebacterium parvum and currently referred to as Cutibac- 
terium acnes) [4] are the most likely causative microorganisms of sarcoidosis. Which of the two infectious agents is more likely to contribute to the pathogenesis among sarcoidosis patients worldwide, however, remains uncertain. This paper reviews the evidence supporting mycobacterial and propionibacterial etiologies of sarcoidosis, and describes a potential pathogenesis based on molecular, immunologic, and histopathologic investigations.

\section{Causative Agents of Granuloma Formation}

Granulomas serve as a protective mechanism to confine poorly degradable extrinsic agents [5]. Foreign body granulomas are formed by agents with weak antigenicity (e.g., surgical sutures), whereas epithelioid cell granulomas are formed by agents with strong antigenicity that can induce an active Th1 immune response [6]. In infectious diseases, microorganisms usually act as both foreign bodies and antigens that induce immunologic responses [7].

Histologically, granulomas start to form as small aggregations of lymphocytes and macrophages around poorly degraded antigens. At the beginning of granuloma formation, macrophages change to epithelioid cells and organize into cell clusters (immature granuloma). As the granuloma progresses, a ball-like cluster of epithelioid cells develops, which is occasionally accompanied by the fusion of macrophages into giant cells (mature granuloma). In granulomas caused by infectious or non-infectious agents, the causative agent is present or has been present in the granulomas [5]. To identify a certain agent as the cause of Th1 granuloma formation, evidence of its presence in the granulomas as well as antigenic hypersensitivity in the patient must be established. This concept of infectious granuloma pathogenesis is the same as that in cases of non-infectious granulomas, such as berylliosis, and must be considered when searching for unknown causative agents of sarcoidosis.

While histopathologic investigations are useful for detecting and locating the causative agents in granulomas, the extrinsic agents or antigens in the granulomas are usually degraded or abolished by the granuloma cells, which have a greater intracellular digestive ability than conventional macrophages [8,9]. Therefore, the causative agent in granulomas may no longer be present, and may only be observed in a few, if any, tissue sections of the granulomas. Because of the degradation process in the granuloma, the causative agent is more likely to be identified in immature granulomas with many inflammatory cells than in mature granulomas with only a few lymphocytes. When a microorganism is detected in granulomas, it is highly suspected as the cause, but even when no microorganism is identified, a microbial etiology cannot be excluded. In infectious granulomas, microbial antigens detected by immunohistochemistry (IHC) are more likely to be degraded or abolished compared with microbial DNA detected by polymerase chain reaction (PCR) or in situ hybridization methods.

\section{Microorganisms Detected in Sarcoid Tissues}

Due to the common features of sarcoidosis and tuberculosis, a mycobacterial cause of sarcoidosis has been suggested since the first description of the disease over a century ago. Although mycobacteria have not been found in sarcoid tissues by conventional histologic and culture techniques [10], a mycobacterial etiology was hypothesized after successful PCR detection of $M$. tuberculosis DNA in sarcoid tissues [11], including granulomas and tissues outside the granulomas. On the basis of a meta-analysis [12] of 31 studies using qualitative PCR published from 1980 to 2006, the odds ratio (OR) for identifying mycobacterial DNA, including M. tuberculosis complex (MTC) and nontuberculous mycobacteria (NTM), in sarcoidosis versus control samples was calculated to be 9.67; mycobacterial DNA was detected in 231 (26\%) of 874 sarcoidosis samples (MTC: 187, NTM: 43, and both: 1) and in 17 (3\%) of 600 control samples (MTC: 13, NTM: 2, and unknown: 2). The detection frequencies in sarcoid tissues were greater than $50 \%$ in seven studies, $20 \%$ to $50 \%$ in eight studies, less than $20 \%$ in nine studies, and $0 \%$ in seven studies. 
In the late 1970s, the Japanese government supported extensive efforts to isolate microorganisms such as bacteria, viruses, and fungi from sarcoid tissues, which unexpectedly led to the isolation of only P. acnes and no other microorganism, including mycobacteria, from sarcoid tissues [13]; P. acnes was isolated from $78 \%$ of 40 sarcoidosis and $21 \%$ of 180 control lymph nodes [14]. Quantitative PCR led to the detection of many P. acnes genomes in $80 \%$ of sarcoidosis samples and only a few P. acnes genomes in $17 \%$ of non-sarcoidosis samples (Figure 1). Many M. tuberculosis genomes were detected in all tuberculosis samples and a few were detected in $13 \%$ of non-tuberculosis samples [15]. Consequently, an international collaborative study on lymph node samples was performed in Japan, Italy, Germany, and England using quantitative real-time PCR [16]; either P. acnes or P. granulosum was detected in all but two sarcoidosis samples. M. tuberculosis was detected in $0 \%$ to $9 \%$ of sarcoidosis samples and $65 \%$ to $100 \%$ of tuberculosis samples. In sarcoid lymph node samples from each country, the observations of propionibacterial genomes far outnumbered those of $M$. tuberculosis genomes.
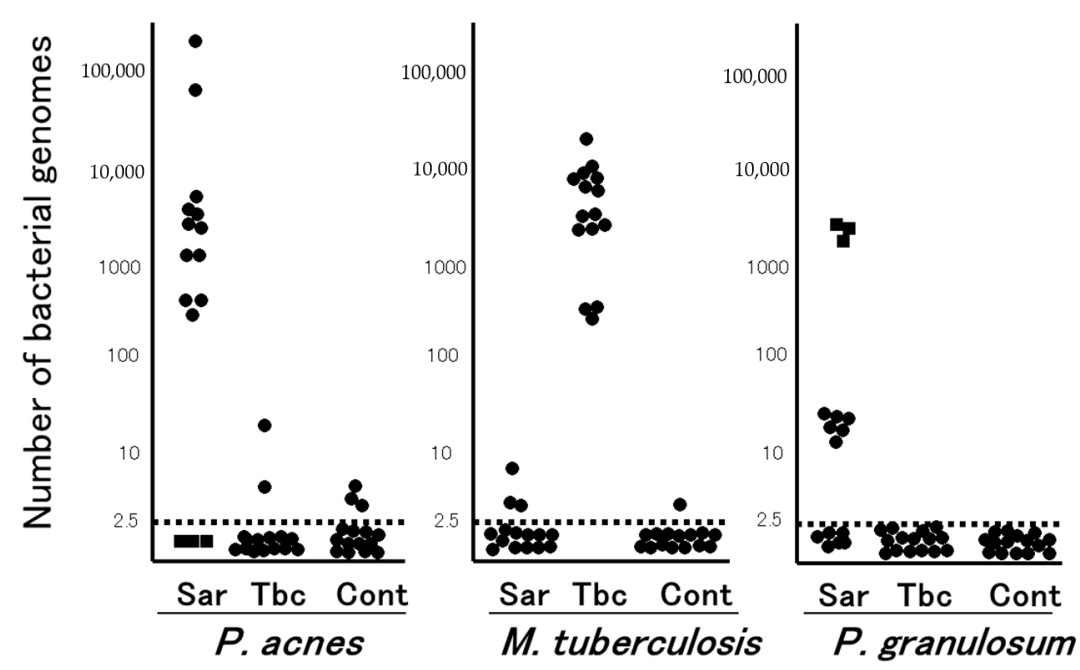

Figure 1. Quantitative PCR for mycobacterial and propionibacterial DNA in sarcoid lymph nodes. Lymph node samples from each of the 15 patients with sarcoidosis (Sar), tuberculosis (Tbc), and gastric cancer (Cont) were used in this study. The horizontal dotted lines show the detection threshold and samples with results below this line are considered negative. Samples without P. acnes detected (as indicated by dotted squares) all contained many P. granulosum (reproduced from Ishige et al. [15] with permission from the Lancet, London).

The results of a recent meta-analysis of 58 studies involving more than 6000 patients in several countries evaluating all types of infectious agents proposed to be associated with sarcoidosis suggested an etiologic link with P. acnes (OR: 18.8, 95\%; CI: 12.6, 28.1) and mycobacteria (OR: 6.8, 95\%; CI: 3.7, 12.4) [17]. Other infectious agents such as Borrelia (OR: 4.8), HHV-8 (OR: 1.5) as well as Rickettsia helvetica, Chlamydia pneumoniae, Epstein-Barr virus, and retrovirus, although suggested by previous investigation, were not associated with sarcoidosis.

Bacterial DNA was detected in lymph nodes from $11(37 \%)$ of 30 sarcoidosis patients (P. acnes: 6, NTM: 3, and others: 2) and 2 (7\%) of 30 control patients (P. acnes: 1 and NTM: 1) using 16S-rRNA gene sequencing [18]. Similarly, high-throughput 16S-rRNA gene sequencing revealed a significantly higher relative abundance of $P$. acnes in lymph node samples obtained from a sarcoidosis group $(0.16 \%)$ than in those obtained from control $(0 \%)$ and tuberculosis $(0 \%)$ cohorts, while the relative abundance of mycobacterium did not differ between sarcoidosis $(0.06 \%)$ and control $(0.05 \%)$ samples [19]. 


\section{Latent Infection and Endogenous Reactivation}

Primary M. tuberculosis infection, most often occurring in childhood, leads to disease in only about $10 \%$ of those infected. Some bacilli in a latent state may remain in the tissues throughout the individual's life and most cases of tuberculosis (secondary tuberculosis) are due to endogenous reactivation of latent infection. M. tuberculosis components are abundant in old tuberculosis lesions with calcification [20] and may persist intracellularly in alveolar and interstitial macrophages, type II pneumocytes, endothelial cells, and fibroblasts in lung tissue without histologic evidence of tuberculosis lesions [21].

P. acnes is a gram-positive anaerobic bacterium that is part of the normal microbiota of the skin, oral cavity, and gastrointestinal and genitourinary tracts [22]. P. acnes survives intracellularly and persists in macrophages without intracellular replication [23]. An overload of $P$. acnes in macrophages induces autophagy and some P. acnes remain persistent in the macrophages [24]. Intracellular P. acnes has been identified in alveolar and sinus macrophages in the lungs and lymph nodes, respectively [25]. Some colonies of $P$. acnes can be isolated from peripheral lungs and mediastinal lymph nodes, even in the absence of inflammation [26]. P. acnes can invade epithelial cells [27,28] and some persist intracellularly [29].

Potential latent infection of M. tuberculosis and P. acnes in the lungs and lymph nodes implies that a few bacterial genomes detected by PCR reflect latent infection unrelated to the disease. Quantitative PCR may help to discriminate between a latent and reactivated status of each bacterium detected in tissues with granulomatous inflammation. Zhou et al. [30] used quantitative PCR for $M$. tuberculosis DNA to differentiate between tuberculosis and sarcoidosis lesions; the genomes were detected in $100 \%$ of tuberculosis samples, $19 \%$ of sarcoidosis samples, and $13 \%$ of control tissue samples (detection specificity for tuberculosis: $81 \%$ with an assay sensitivity of $10^{2}$ genome copies $/ \mathrm{mL}$ ), whereas the specificity was increased to $98 \%$ with a cut-off value of $1.14 \times 10^{3}$ genome copies $/ \mathrm{mL}$. They also reported the results of quantitative reverse transcription-PCR for propionibacterial rRNA using lymph node samples [31]; P. acnes or P. granulosum rRNA was detected in $74 \%$ of 65 sarcoidosis samples, $9 \%$ of 45 tuberculosis samples, and $6 \%$ of 50 control samples. With a cut-off value of 50 genome copies $/ \mathrm{mL}$, the propionibacterial $\mathrm{rRNA}$ was positive in an additional $79 \%$ of 24 sarcoidosis samples and an additional $4 \%$ of 22 tuberculosis samples (detection specificity for sarcoidosis: 96\%). Rotsinger et al. [32] used quantitative real-time PCR for multiple mycobacterial genes and reported that 1 or more of the 6 mycobacterial genes was detected in $85 \%$ of 33 sarcoidosis samples and $7 \%$ of 30 control samples, although the quantitative results were not described.

\section{Immune Responses to M. tuberculosis and P. acnes}

Fang et al. [33] conducted a meta-analysis of studies on immune responses to mycobacteria, which included nine reports on T-cell immune responses and four reports on humoral immune responses. The stimulating antigens used in most studies were from $M$. tuberculosis, including early secretory antigenic target (ESAT)- 6 and mycobacterial catalase-peroxidase (mKatG). In many reports, the T-cell or humoral immune responses were significantly higher in sarcoidosis patients than in the control group. Therefore, the authors concluded that $M$. tuberculosis may be associated with the pathogenesis of sarcoidosis. According to the results of tuberculin skin tests, however, the control group included purified protein derivative (PPD)-negative, PPD-positive, and PPD-unknown cases, and the difference between the sarcoidosis and control groups was no longer significant when compared with the PPD-positive healthy control group. Sarcoidosis patients may be prone to latent $M$. tuberculosis and P. acnes infection due to unknown host factors including decreased expression levels of nucleotide-binding oligomerization domain-containing protein 1 (NOD1) in response to intracellular infection by these gram-positive bacteria [28].

The QuantiFERON-TB Gold test is a simple interferon-gamma (IFN- $\gamma$ ) release assay with two stimulating antigens, ESAT- 6 and culture filtrate protein-10, both specific to $M$. tuberculosis infection. Several studies reported the positivity rate in sarcoidosis patients-3\% 
in Japan [34], 7\% in Denmark [35], 21\% in Poland [36], and 34\% in India [37]—with no significant difference in any report between sarcoidosis patients and healthy controls in each country. In studies that simultaneously investigated the reactivities to PPD, ESAT6 , and culture filtrate protein-10, IFN-y release by peripheral blood mononuclear cells and bronchoalveolar lavage (BAL) cells in response to these $M$. tuberculosis antigens did not differ significantly between patients with sarcoidosis and those with control lung diseases $[38,39]$.

Furusawa et al. [40] reported significant differences in the Th1/Th17 responses of peripheral blood mononuclear cells between sarcoidosis and control groups when stimulated with viable P. acnes but not with viable MTC (bacillus Calmette-Guérin) or ESAT-6; the increased interleukin-2 and decreased interleukin-17 responses to P. acnes suggested an imbalance of Th1/Th17 immune responses to the commensal bacterium in sarcoidosis patients. Cellular and humoral immune responses to P. acnes trigger factor [41] and catalase [42] are increased in Japanese sarcoidosis patients. German patients with sarcoidosis also had high levels of specific antibodies to P. acnes in the BAL fluid, and the BAL cells in those patients produced inflammatory cytokines (tumor necrosis factor alpha and granulocyte-macrophage colony-stimulating factor) upon stimulation with heat-killed $P$. acnes [43]. IFN-y release from BAL cells upon stimulation with the supernatant of boiled $P$. acnes did not differ between sarcoidosis and control patients in the United States [44].

Immune responses to potential infectious agents of sarcoidosis should be considered together with the microorganisms detected in sarcoid granulomas, because immunologic reactivities to infectious agents reflect current and past infection, including latent infection unrelated to the cause of the granuloma formation.

\section{M. tuberculosis and P. acnes in Sarcoid Granulomas}

Four studies investigated the localization of mycobacterial components in sarcoid tissues. M. tuberculosis KatG and 16S-rRNA DNA were detected in formalin-fixed paraffinembedded (FFPE) sarcoid tissues by in situ hybridization with tyramide signal amplification [45]. Mycobacterial ESAT-6 was detected by matrix-assisted laser desorption-ionization imaging mass spectrometry at sites of granulomatous inflammation in snap-frozen sarcoid specimens [44]. Mycobacterial gyrA nucleic acids were localized to sites of granuloma formation by a novel in situ RNA detection kit (RNAscope) [32]. In only one report, mycobacterial antigens were located by IHC with commercially available monoclonal antibodies; $M$. tuberculosis hsp70, hsp65, and hsp16 were detected in all cases of snap-frozen sarcoid lymph nodes, while $M$. tuberculosis DNA was detected in $6 \%$ of the sarcoid tissues in the study [46]. In the four studies mentioned above, the methods and tissues used to locate M. tuberculosis DNA or antigens in sarcoid granulomas varied, and none of the results have been validated by others. Additionally, IHC with a commercially available LAM antibody (D372-3, MBL, Japan), which reacts with mycobacterial lipoarabinomannan in FFPE tissues, detected positive signals in tuberculosis granulomas [20], whereas no signal was detected in sarcoid granulomas (Y. Eishi, unpublished observation).

P. acnes 16S-rRNA DNA was detected in sarcoid granulomas of FFPE lymph nodes by in situ hybridization with signal amplification by catalyzed reporter deposition [47]. This method was also used to detect $P$. acnes DNA in granulomas of necrotizing sarcoid granulomatosis [48]. The commercially available PAB antibody (D371-3, MBL) is a P. acnes-specific monoclonal antibody that reacts with cell membrane-bound lipoteichoic acid of the bacterium in FFPE tissues. IHC with the PAB antibody has detected P. acnes in sarcoid granulomas of various organs (Figure 2). Positive signals in sarcoid granulomas were found in $88 \%$ of 81 Japanese and $89 \%$ of 38 German lymph node samples, whereas no signal was detected in non-sarcoidosis granulomas, such as tuberculosis and sarcoid reaction [25]. Histopathologic analysis suggested latent infection and intracellular proliferation of P. acnes in sarcoid lymph nodes (Figure 3) $[25,49,50]$. The frequent identification of P. acnes in sarcoid granulomas of originally aseptic organs, such as the heart [51] and eyeball [52,53], provides further evidence linking this commensal bacterium to the cause of 
granuloma formation. Many case reports with P. acnes detected in granulomas, including pulmonary sarcoidosis [54,55], cutaneous sarcoidosis [56-62], nasal sarcoidosis [63], and neurosarcoidosis [64,65], have been published. These cases in which P. acnes was identified in granulomas by IHC with the PAB antibody were recently termed $P$. acnes-associated sarcoidosis [55,64-68].

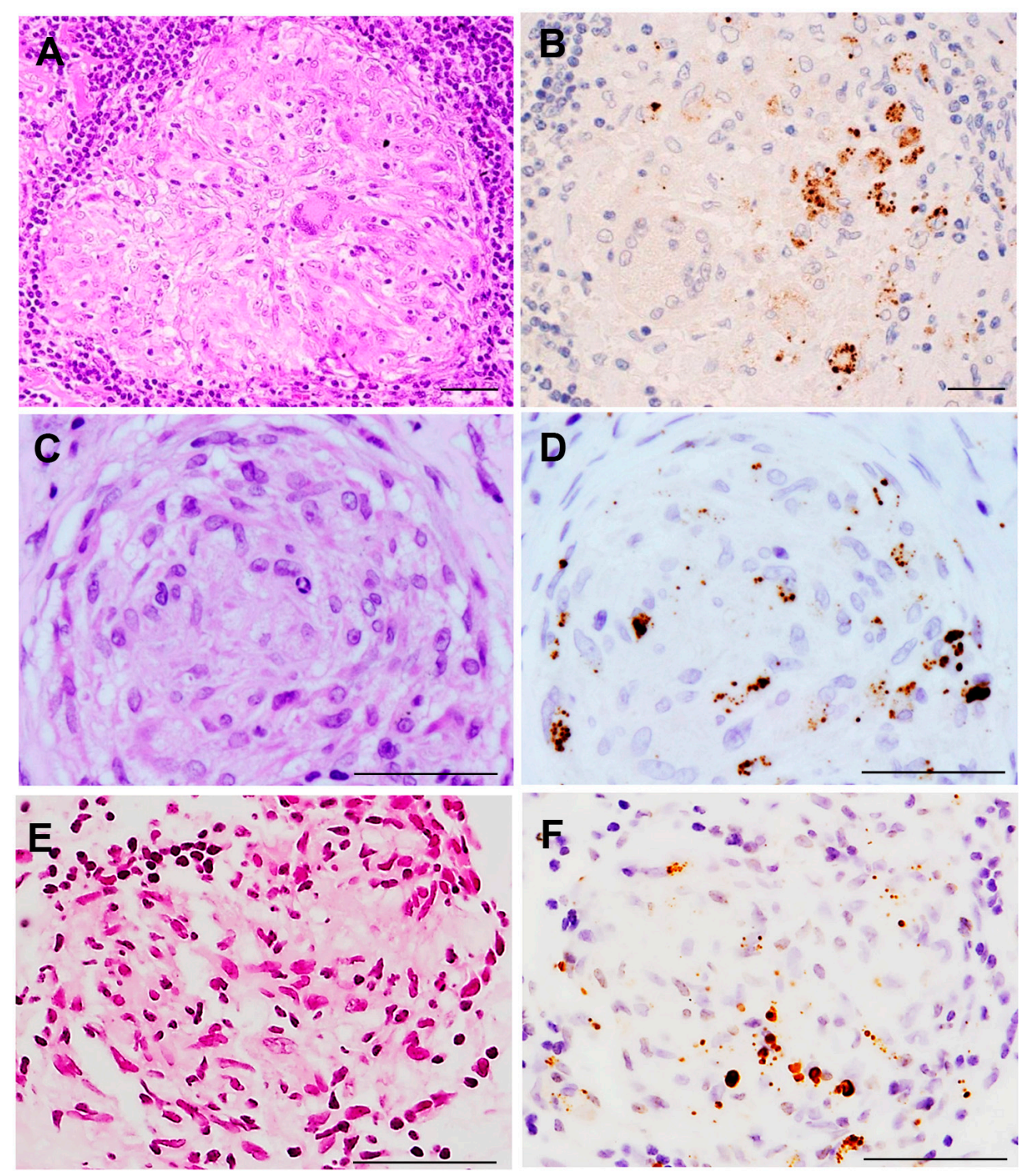

Figure 2. P. acnes in sarcoid granulomas detected by immunohistochemistry with PAB antibody. Hematoxylin-eosin stain and immunohistochemistry with P. acnes-specific PAB antibody are shown pairwise. PAB-reactive $P$. acnes (resulting in brown color) are observed in non-caseating epithelioid cell granulomas of the lymph node (A,B), lung (C,D), and ocular epiretinal membrane (E,F) from patients with sarcoidosis. Mainly small round and occasionally large ovoid positive-signals are observed in granuloma cells, irrespective of the sites at which the granuloma formed. All photos are original. Scale bar: $50 \mu \mathrm{m}$. 


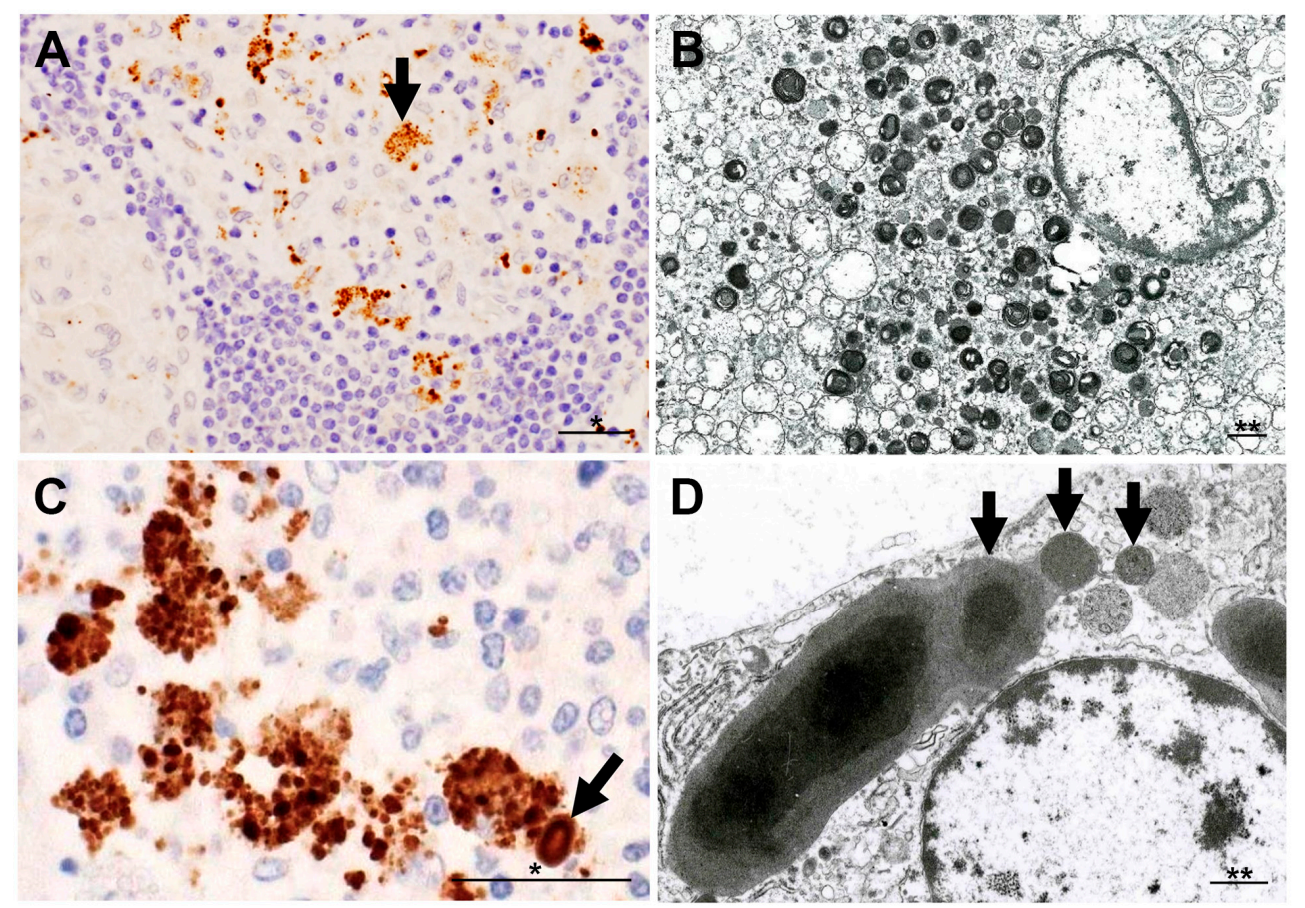

Figure 3. Morphologic features of intracellular P. acnes proliferation in sarcoid lymph nodes. Most of the PAB-reactive P. acnes in granuloma cells, such as indicated by an arrow (A), are degraded showing lamellar body formation (B). Intracellular proliferation of P. acnes is suggested in an early focus of paracortical granuloma composed of a cluster of swollen macrophages filled with many PAB-reactive small round bodies with a similarly PAB-reactive Hamazaki-Wesenberg (HW) body (an arrow) (C). HW bodies are found mainly in sinus macrophages rarely accompanied by small round bodies (arrows) sprouting from the large ovoid HW body (D). All photos are original. Scale bar: ${ }^{*} 50 \mu \mathrm{m},{ }^{* *} 1 \mu \mathrm{m}$.

\section{Potential Pathogenesis of Sarcoidosis}

The absence of active mycobacterial infection suggests that only some specific, poorly degraded mycobacterial components act as antigens and contribute to granulomatous inflammation in subjects with Th1 hypersensitivity [33]. M. tuberculosis KatG is the most implicated tissue antigen and target of the adoptive immune response in sarcoidosis [69]. Recent studies proposed a role for serum amyloid A in promoting a progressive and chronic granulomatous inflammation in the absence of ongoing infection [70], and even a role for vimentin as a possible autoantigen in sarcoidosis patients [71]. It is important, however, to demonstrate the causative agents in sarcoid granulomas. Detection of mycobacterial nucleic acids in granulomas does not necessarily indicate co-localization of the bacterial proteins in the granulomas. IHC with anti-mKatG or other anti-mycobacterium antibodies may be useful for diagnosing $M$. tuberculosis-associated sarcoidosis.

Histopathologic evidence of active P. acnes infection continues to accumulate (Figure 4). $P$. acnes induces interleukin-17 and IFN-y production by T-cells [72], suggesting that mixed Th1/Th17 responses are promoted by this bacterium [73]. The association of P. acnes and autophagy is known [24] and the potential dysfunction of mTOR, Rac1, and autophagy-related pathways in sarcoidosis is suggested [74-76]. Notably, the host-commensal relationship relies on a unique Treg cell population that mediates tolerance to bacterial antigens during a defined developmental window [77]. Intravenous or intratracheal P. acnes inoculation causes self-limiting granulomatous inflammation in the liver [78,79] and lung [80,81], respectively. Interestingly, extrapulmonary sensitization to $P$. acnes induces pulmonary Th1 granulomas, primarily in subpleural and peribroncho-vascular regions, suggesting that commensal pulmonary P. acnes primes the host for the development of sarcoid-like pulmonary granulomatosis $[82,83]$. 

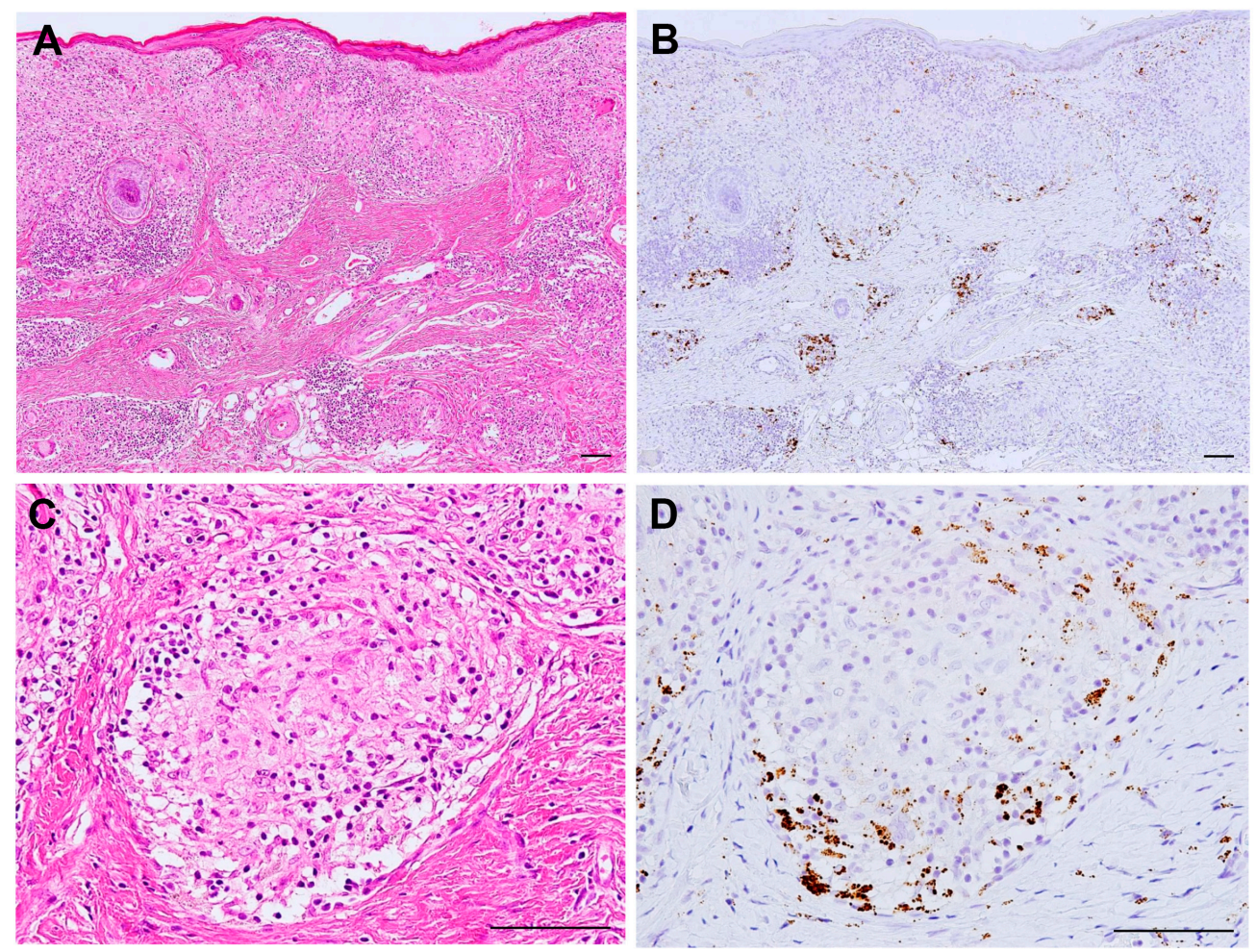

Figure 4. Active P. acnes infection in granulomatous inflammation of cutaneous sarcoidosis. Hematoxylin-eosin stain and immunohistochemistry with P. acnes-specific PAB antibody are shown pairwise. Many granulomas are found in the dermis with prominent lymphocytic infiltration (A). Many PAB-reactive P. acnes (in brown color) are found corresponding to the areas of granulomatous inflammation (B). In a non-caseating epithelioid cell granuloma (C), P. acnes is abundant in the peripheral area with more lymphocytic infiltration (D). All photos are original. Scale bar: $100 \mu \mathrm{m}$.

According to the results of IHC with the PAB antibody, granulomatous inflammation in sarcoidosis patients may be caused by intracellular P. acnes proliferation at sites with latent infection (Figure 5). In sarcoid lymph nodes, many PAB-reactive P. acnes are bound with immunoglobulins in sinus macrophages, whereas those in paracortical granuloma cells are mostly free from immunoglobulins [84]. The difference between P. acnes with or without immunoglobulins suggests that $P$. acnes-derived insoluble immune complexes are formed extracellularly after intracellular proliferation and phagocytosed in sinus macrophages, some of which may escape local phagocytosis and spread via the lymphatic system and bloodstream.

Translocation of P. acnes after local proliferation at the primary sites of latent infection (usually in the lung and mediastinal lymph nodes) may cause new latent infection (primarily in vascular endothelial cells) in systemic organs where later reactivation causes granuloma formation in predisposed individuals with Th1 hypersensitivity to the symbiotic bacterium (Figure 6) [49,50]. Alternatively, local entry and subsequent latent infection other than systemic spread of P. acnes may occur, such as in scar or tattoo sarcoidosis with a previous history of epidermal disruption and the salivary gland sarcoidosis with potential transductal epithelial infection. 


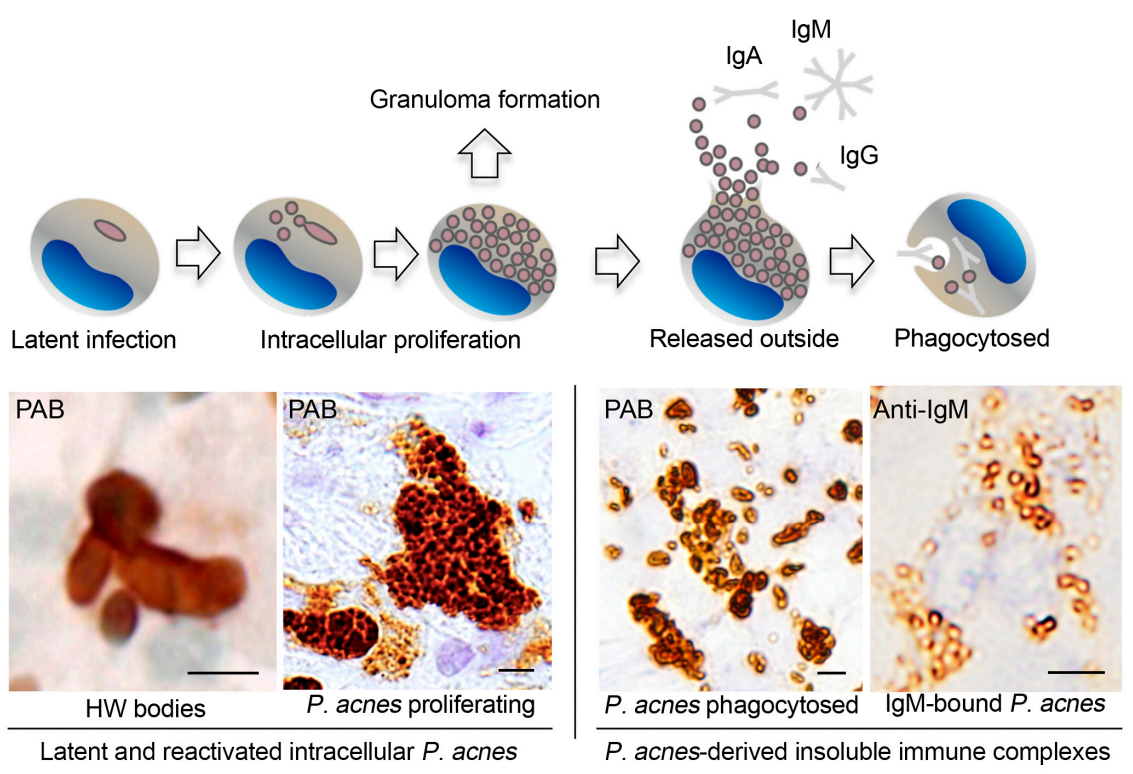

Figure 5. Intracellular proliferation of latent P. acnes followed by insoluble immune complex formation in sarcoid lymph nodes. Representative immunohistochemical features revealed by $\mathrm{PAB}$ or anti-IgM antibodies are shown below the illustrated macrophages with each stage of intracellular P. acnes manifestation. These findings imply that intracellular proliferation of latent $P$. acnes in paracortical macrophages triggers granuloma formation in sarcoidosis patients. PAB-reactive small round bodies bound with immunoglobulins (mainly $\operatorname{IgM}$ and $\operatorname{IgA}$ ) are formed extracellularly and phagocytosed by sinus macrophages after release from paracortical macrophages with proliferating $P$. acnes that are free of immunoglobulins. Some of the P. acnes-derived immune complexes may escape local phagocytosis. All photos are original. Scale bar: $5 \mu \mathrm{m}$. HW, Hamazaki-Wesenberg.

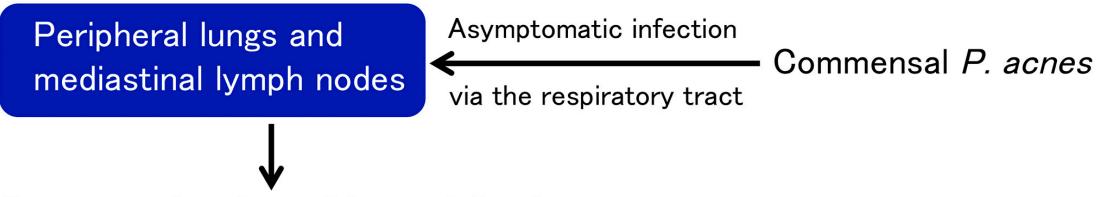

Events at the sites of latent infection

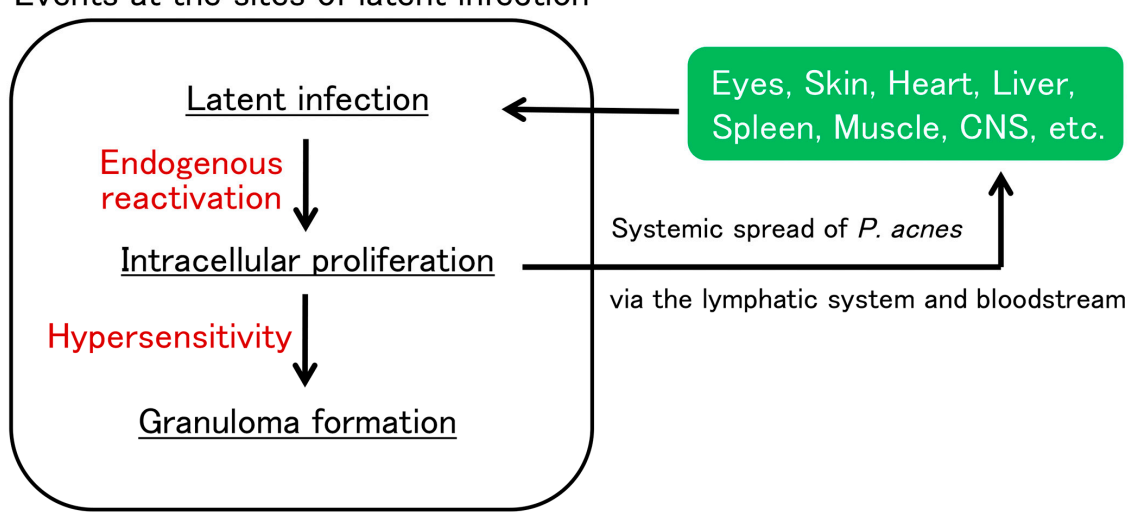

Figure 6. Potential pathogenesis of sarcoidosis as an allergic endogenous infection caused by P. acnes. Commensal $P$. acnes causes asymptomatic intracellular infection and persists in the peripheral lungs and mediastinal lymph nodes. Latent $P$. acnes is activated endogenously under certain conditions and proliferates intracellularly at the sites of latent infection. In patients with Th1 hypersensitivity to $P$. acnes, granulomatous inflammation is triggered by intracellular proliferation of the bacterium. Extracellular P. acnes that escaped granulomatous confinement or local phagocytosis potentially cause new latent infection in multiple organs via the lymphatic system and bloodstream dissemination. The latent infection spread in systemic organs can be simultaneously reactivated by additional triggering events, leading to granuloma formation at all sites of latent infection. 
Reactivation at the sites of latent infection may be triggered under certain host conditions, such as physical or mental stress, in sarcoidosis patients [85], as observed in patients with herpes zoster [86]. Tumor necrosis factor alpha inhibitors may cause tuberculosis or sarcoidosis by reactivating latent $M$. tuberculosis [87] or P. acnes [55] at sites with latent infection. Sarcoidosis is also induced by immune checkpoint inhibitors [88], which might be associated with disrupted peripheral T-cell tolerance against not only cancer cells, but also symbiotic P. acnes.

\title{
8. Conclusions
}

The results of many molecular and immunologic studies supporting mycobacterial and propionibacterial etiologies of sarcoidosis are complicated because of potential latent infection by both microorganisms in deep organs such as the lungs and lymph nodes. A mycobacterial etiology is based on hypersensitivity to some pathogenic antigens without active infection. A propionibacterial etiology is based on active $P$. acnes infection with the bacterium reliably detected in granulomas. P. acnes and M. tuberculosis are the only microorganisms with sufficient evidence for an etiologic role in sarcoidosis. More of the available histopathologic data support $P$. acnes as a cause of sarcoidosis compared with $M$. tuberculosis, suggesting that an endogenous infection by normally symbiotic $P$. acnes may cause granuloma formation in some predisposed individuals with Th1 hypersensitivity against intracellular proliferation of latent $P$. acnes triggered by certain host or drug-induced conditions. In the histopathologic diagnosis of sarcoidosis, M. tuberculosis-associated and $P$. acnes-associated sarcoidosis will possibly be differentiated in some patients by IHC for each etiologic diagnosis and potential antimicrobial intervention of sarcoidosis.

Author Contributions: T.Y. and Y.E. wrote the first draft of the manuscript. U.C., A.M., J.G., K.U. and K.O. contributed to the revision and drafting of the manuscript. The authors thank SciTechEdit International LLC, Highlands Ranch, CO, for editing a draft of the manuscript, which was funded by a research grant (No. 1536) donated to Tokyo Medical and Dental University. All authors have read and agreed to the published version of the manuscript.

Funding: This research received no external funding.

Conflicts of Interest: All authors declare that they have no competing interest.

\begin{abstract}
Abbreviations
16S-rRNA: 16S-ribosomal ribonucleic acid; BAL, bronchoalveolar lavage; CI, confidence interval; DNA, deoxyribonucleic acid; ESAT-6, early secretory antigenic target-6; FFPE, formalin-fixed paraffin-embedded; HHV-8, human herpesvirus-8; HW, Hamazaki-Wesenberg; IFN-y, interferongamma; IHC, immunohistochemistry; $\mathrm{mKatG}$, mycobacterial catalase-peroxidase; MTC, M. tuberculosis complex; mTOR, mechanistic target of rapamycin; NOD1, nucleotide-binding oligomerization domain-containing protein 1; NTM, nontuberculous mycobacteria; OR, odds ratio; PCR, polymerase chain reaction; PPD, purified protein derivative; Rac1, Ras-related C3 botulinum toxin substrate 1.
\end{abstract}

\section{References}

1. Valeyre, D.; Prasse, A.; Nunes, H.; Uzunhan, Y.; Brillet, P.-Y.; Müller-Quernheim, J. Sarcoidosis. Lancet 2014, 383 , $1155-1167$. [CrossRef]

2. Beijer, E.; Veltkamp, M.; Meek, B.; Moller, D.R. Etiology and Immunopathogenesis of Sarcoidosis: Novel Insights. Semin. Respir. Crit. Care Med. 2017, 38, 404-416. [CrossRef]

3. Casadevall, A.; Pirofski, L.A. Host-pathogen interactions: Redefining the basic concepts of virulence and pathogenicity. Infect. Immun. 1999, 67, 3703-3713. [CrossRef]

4. Alexeyev, O.A.; Dekio, I.; Layton, A.M.; Li, H.; Hughes, H.; Morris, T.; Zouboulis, C.C.; Patrick, S. Why we continue to use the name Propionibacterium acnes. Br. J. Dermatol. 2018, 179, 1227. [CrossRef]

5. Sell, S. Granulomatous Reactions. In Immunology Immunopathology and Immunity; Elsevier Science Publishing Company, Inc.: Amsterdam, The Netherlands, 1987; pp. 529-544.

6. Pagán, A.J.; Ramakrishnan, L. The Formation and Function of Granulomas. Annu. Rev. Immunol. 2018, 36, 639-665. [CrossRef]

7. Zumla, A.; James, D.G. Granulomatous infections: Etiology and classification. Clin. Infect. Dis. 1996, 23, 146-158. [CrossRef] 
8. Carr, I. Sarcoid macrophage giant cells. Ultrastructure and lysozyme content. Virchows Arch. B Cell Pathol. Incl. Mol. Pathol. 1980, 32, 147-155. [CrossRef]

9. Okabe, T.; Suzuki, A.; Ishikawa, H.; Yotsumoto, H.; Ohsawa, N. Cells originating from sarcoid granulomas in vitro. Am. Rev. Respir. Dis. 1981, 124, 608-612. [CrossRef]

10. Wilsher, M.L.; Menzies, R.E.; Croxson, M.C. Mycobacterium tuberculosis DNA in tissues affected by sarcoidosis. Thorax 1998, 53, 871-874. [CrossRef]

11. Saboor, S.A.; Johnson, N.M.; McFadden, J. Detection of mycobacterial DNA in sarcoidosis and tuberculosis with polymerase chain reaction. Lancet 1992, 339, 1012-1015. [CrossRef]

12. Gupta, D.; Agarwal, R.; Aggarwal, A.N.; Jindal, S.K. Molecular evidence for the role of mycobacteria in sarcoidosis: A metaanalysis. Eur. Respir. J. 2007, 30, 508-516. [CrossRef]

13. Homma, J.Y.; Abe, C.; Chosa, H.; Ueda, K.; Saegusa, J.; Nakayama, M.; Homma, H.; Washizaki, M.; Okano, H. Bacteriological investigation on biopsy specimens from patients with sarcoidosis. Jpn. J. Exp. Med. 1978, 48, 251-255. [PubMed]

14. Abe, C.; Iwai, K.; Mikami, R.; Hosoda, Y. Frequent isolation of Propionibacterium acnes from sarcoidosis lymph nodes. Zentralbl. Bakteriol. Mikrobiol. Hyg. A 1984, 256, 541-547. [CrossRef]

15. Ishige, I.; Usui, Y.; Takemura, T.; Eishi, Y. Quantitative PCR of mycobacterial and propionibacterial DNA in lymph nodes of Japanese patients with sarcoidosis. Lancet 1999, 354, 120-123. [CrossRef]

16. Eishi, Y.; Suga, M.; Ishige, I.; Kobayashi, D.; Yamada, T.; Takemura, T.; Takizawa, T.; Koike, M.; Kudoh, S.; Costabel, U.; et al. Quantitative analysis of mycobacterial and propionibacterial DNA in lymph nodes of Japanese and European patients with sarcoidosis. J. Clin. Microbiol. 2002, 40, 198-204. [CrossRef]

17. Esteves, T.; Aparicio, G.; Garcia-Patos, V. Is there any association between Sarcoidosis and infectious agents?: A systematic review and meta-analysis. BMC Pulm. Med. 2016, 16, 165. [CrossRef]

18. Robinson, L.A.; Smith, P.; Sengupta, D.J.; Prentice, J.L.; Sandin, R.L. Molecular analysis of sarcoidosis lymph nodes for microorganisms: A case-control study with clinical correlates. BMJ Open 2013, 3, e004065. [CrossRef]

19. Zhao, M.-M.; Du, S.-S.; Li, Q.-H.; Chen, T.; Qiu, H.; Wu, Q.; Chen, S.-S.; Zhou, Y.; Zhang, Y.; Hu, Y.; et al. High throughput 16SrRNA gene sequencing reveals the correlation between Propionibacterium acnes and sarcoidosis. Respir. Res. 2017, 18, 28. [CrossRef]

20. Iida, T.; Uchida, K.; Lokman, N.; Furukawa, A.; Suzuki, Y.; Kumasaka, T.; Takemura, T.; Kawachi, H.; Akashi, T.; Eishi, Y. Calcified Granulomatous Lung Lesions Contain Abundant Mycobacterium tuberculosis Components. Mycobact. Dis. 2013, 4. [CrossRef]

21. Hernández-Pando, R.; Jeyanathan, M.; Mengistu, G.; Aguilar, D.; Orozco, H.; Harboe, M.; Rook, G.A.; Bjune, G. Persistence of DNA from Mycobacterium tuberculosis in superficially normal lung tissue during latent infection. Lancet 2000, 356, $2133-2138$. [CrossRef]

22. McLaughlin, J.; Watterson, S.; Layton, A.M.; Bjourson, A.J.; Barnard, E.; McDowell, A. Propionibacterium acnes and Acne Vulgaris: New Insights from the Integration of Population Genetic, Multi-Omic, Biochemical and Host-Microbe Studies. Microorganisms 2019, 7, 128. [CrossRef] [PubMed]

23. Fischer, N.; Mak, T.N.; Shinohara, D.B.; Sfanos, K.S.; Meyer, T.F.; Brüggemann, H. Deciphering the intracellular fate of Propionibacterium acnes in macrophages. Biomed. Res. Int. 2013, 2013, 603046. [CrossRef]

24. Nakamura, T.; Furukawa, A.; Uchida, K.; Ogawa, T.; Tamura, T.; Sakonishi, D.; Wada, Y.; Suzuki, Y.; Ishige, Y.; Minami, J.; et al. Autophagy Induced by Intracellular Infection of Propionibacterium acnes. PLoS ONE 2016, 11, e0156298. [CrossRef] [PubMed]

25. Negi, M.; Takemura, T.; Guzman, J.; Uchida, K.; Furukawa, A.; Suzuki, Y.; Iida, T.; Ishige, I.; Minami, J.; Yamada, T.; et al. Localization of Propionibacterium acnes in granulomas supports a possible etiologic link between sarcoidosis and the bacterium. Mod. Pathol. 2012, 25, 1284-1297. [CrossRef]

26. Ishige, I.; Eishi, Y.; Takemura, T.; Kobayashi, I.; Nakata, K.; Tanaka, I.; Nagaoka, S.; Iwai, K.; Watanabe, K.; Takizawa, T.; et al. Propionibacterium acnes is the most common bacterium commensal in peripheral lung tissue and mediastinal lymph nodes from subjects without sarcoidosis. Sarcoidosis Vasc. Diffus. Lung Dis. 2005, 22, 33-42.

27. Furukawa, A.; Uchida, K.; Ishige, Y.; Ishige, I.; Kobayashi, I.; Takemura, T.; Yokoyama, T.; Iwai, K.; Watanabe, K.; Shimizu, S.; et al. Characterization of Propionibacterium acnes isolates from sarcoid and non-sarcoid tissues with special reference to cell invasiveness, serotype, and trigger factor gene polymorphism. Microb. Pathog. 2009, 46, 80-87. [CrossRef]

28. Tanabe, T.; Ishige, I.; Suzuki, Y.; Aita, Y.; Furukawa, A.; Ishige, Y.; Uchida, K.; Suzuki, T.; Takemura, T.; Ikushima, S.; et al. Sarcoidosis and NOD1 variation with impaired recognition of intracellular Propionibacterium acnes. Biochim. Biophys. Acta 2006, 1762, 794-801. [CrossRef]

29. Bae, Y.; Ito, T.; Iida, T.; Uchida, K.; Sekine, M.; Nakajima, Y.; Kumagai, J.; Yokoyama, T.; Kawachi, H.; Akashi, T.; et al. Intracellular Propionibacterium acnes infection in glandular epithelium and stromal macrophages of the prostate with or without cancer. PLOS ONE 2014, 9, e90324. [CrossRef]

30. Zhou, Y.; Li, H.P.; Li, Q.H.; Zheng, H.; Zhang, R.X.; Chen, G.; Baughman, R.P. Differentiation of sarcoidosis from tuberculosis using real-time PCR assay for the detection and quantification of Mycobacterium tuberculosis. Sarcoidosis Vasc. Diffus. Lung Dis. 2008, 25, 93-99.

31. Zhou, Y.; Wei, Y.-R.; Zhang, Y.; Du, S.-S.; Baughman, R.P.; Li, H.-P. Real-time quantitative reverse transcription-polymerase chain reaction to detect propionibacterial ribosomal RNA in the lymph nodes of Chinese patients with sarcoidosis. Clin. Exp. Immunol. 2015, 181, 511-517. [CrossRef] 
32. Rotsinger, J.E.; Celada, L.J.; Polosukhin, V.V.; Atkinson, J.B.; Drake, W.P. Molecular Analysis of Sarcoidosis Granulomas Reveals Antimicrobial Targets. Am. J. Respir. Cell Mol. Biol. 2016, 55, 128-134. [CrossRef]

33. Fang, C.; Huang, H.; Xu, Z. Immunological Evidence for the Role of Mycobacteria in Sarcoidosis: A Meta-Analysis. PLoS ONE 2016, 11, e0154716. [CrossRef]

34. Inui, N.; Suda, T.; Chida, K. Use of the QuantiFERON-TB Gold test in Japanese patients with sarcoidosis. Respir. Med. 2008, 102, 313-315. [CrossRef]

35. Milman, N.; Søborg, B.; Svendsen, C.B.; Andersen, A.B. Quantiferon test for tuberculosis screening in sarcoidosis patients. Scand. J. Infect. Dis. 2011, 43, 728-735. [CrossRef]

36. Piotrowski, W.J.; Adam, B.; Gwadera, Ł.; Kumor-Kisielewska, A.; Fijałkowski, M.; Kurmanowska, Z.; Marczak, J.; Górski, W.; Angowski, W.; Górski, P.; et al. QuantiFERON-TB-GOLD In-Tube in patients with sarcoidosis. Adv. Respir. Med. 2018, 86, 234-239. [CrossRef] [PubMed]

37. Gupta, D.; Kumar, S.; Aggarwal, A.N.; Verma, I.; Agarwal, R. Interferon gamma release assay (QuantiFERON-TB Gold In Tube) in patients of sarcoidosis from a population with high prevalence of tuberculosis infection. Sarcoidosis Vasc. Diffus. Lung Dis. 2011, $28,95-101$.

38. Hörster, R.; Kirsten, D.; Gaede, K.I.; Jafari, C.; Strassburg, A.; Greinert, U.; Kalsdorf, B.; Ernst, M.; Lange, C. Antimycobacterial immune responses in patients with pulmonary sarcoidosis. Clin. Respir. J. 2009, 3, 229-238. [CrossRef] [PubMed]

39. Hofland, R.W.; Thijsen, S.F.; Bouwman, J.; van der Wel, M.; Bossink, A.W.J. Sarcoidosis and Purified Protein Derivative reactivity. Sarcoidosis Vasc. Diffus. lung Dis. 2014, 31, 142-148.

40. Furusawa, H.; Suzuki, Y.; Miyazaki, Y.; Inase, N.; Eishi, Y. Th1 and Th17 immune responses to viable Propionibacterium acnes in patients with sarcoidosis. Respir. Investig. 2012, 50, 104-109. [CrossRef]

41. Ebe, Y.; Ikushima, S.; Yamaguchi, T.; Kohno, K.; Azuma, A.; Sato, K.; Ishige, I.; Usui, Y.; Takemura, T.; Eishi, Y. Proliferative response of peripheral blood mononuclear cells and levels of antibody to recombinant protein from Propionibacterium acnes DNA expression library in Japanese patients with sarcoidosis. Sarcoidosis Vasc. Diffus. Lung Dis. 2000, 17, $256-265$.

42. Yorozu, P.; Furukawa, A.; Uchida, K.; Akashi, T.; Kakegawa, T.; Ogawa, T.; Minami, J.; Suzuki, Y.; Awano, N.; Furusawa, H.; et al. Propionibacterium acnes catalase induces increased Th1 immune response in sarcoidosis patients. Respir. Investig. 2015, 53, 161-169. [CrossRef]

43. Schupp, J.C.; Tchaptchet, S.; Lützen, N.; Engelhard, P.; Müller-Quernheim, J.; Freudenberg, M.A.; Prasse, A. Immune response to Propionibacterium acnes in patients with sarcoidosis-in vivo and in vitro. BMC Pulm. Med. 2015, 15, 75. [CrossRef] [PubMed]

44. Oswald-Richter, K.A.; Beachboard, D.C.; Seeley, E.H.; Abraham, S.; Shepherd, B.E.; Jenkins, C.A.; Culver, D.A.; Caprioli, R.M.; Drake, W.P. Dual analysis for mycobacteria and propionibacteria in sarcoidosis BAL. J. Clin. Immunol. 2012, 32, 1129-1140. [CrossRef]

45. Song, Z.; Marzilli, L.; Greenlee, B.M.; Chen, E.S.; Silver, R.F.; Askin, F.B.; Teirstein, A.S.; Zhang, Y.; Cotter, R.J.; Moller, D.R. Mycobacterial catalase-peroxidase is a tissue antigen and target of the adaptive immune response in systemic sarcoidosis. J. Exp. Med. 2005, 201, 755-767. [CrossRef]

46. Dubaniewicz, A.; Dubaniewicz-Wybieralska, M.; Sternau, A.; Zwolska, Z.; Izycka-Swieszewska, E.; Augustynowicz-Kopec, E.; Skokowski, J.; Singh, M.; Zimnoch, L. Mycobacterium tuberculosis complex and mycobacterial heat shock proteins in lymph node tissue from patients with pulmonary sarcoidosis. J. Clin. Microbiol. 2006, 44, 3448-3451. [CrossRef]

47. Yamada, T.; Eishi, Y.; Ikeda, S.; Ishige, I.; Suzuki, T.; Takemura, T.; Takizawa, T.; Koike, M. In situ localization of Propionibacterium acnes DNA in lymph nodes from sarcoidosis patients by signal amplification with catalysed reporter deposition. J. Pathol. 2002, 198, 541-547. [CrossRef]

48. Arai, T.; Inoue, Y.; Eishi, Y.; Yamamoto, S.; Sakatani, M. Propionibacterium acnes in granulomas of a patient with necrotising sarcoid granulomatosis. Thorax 2008, 63, 90-91. [CrossRef]

49. Eishi, Y. Etiologic aspect of sarcoidosis as an allergic endogenous infection caused by Propionibacterium acnes. Biomed. Res. Int. 2013, 2013, 935289. [CrossRef]

50. Eishi, Y. Etiologic link between sarcoidosis and Propionibacterium acnes. Respir. Investig. 2013, 51, 56-68. [CrossRef]

51. Asakawa, N.; Uchida, K.; Sakakibara, M.; Omote, K.; Noguchi, K.; Tokuda, Y.; Kamiya, K.; Hatanaka, K.C.; Matsuno, Y.; Yamada, S.; et al. Immunohistochemical identification of Propionibacterium acnes in granuloma and inflammatory cells of myocardial tissues obtained from cardiac sarcoidosis patients. PLoS ONE 2017, 12, e0179980. [CrossRef] [PubMed]

52. Goto, H.; Usui, Y.; Umazume, A.; Uchida, K.; Eishi, Y. Propionibacterium acnes as a possible pathogen of granuloma in patients with ocular sarcoidosis. Br. J. Ophthalmol. 2017, 101, 1510-1513. [CrossRef]

53. Nagata, K.; Eishi, Y.; Uchida, K.; Yoneda, K.; Hatanaka, H.; Yasuhara, T.; Nagata, M.; Sotozono, C.; Kinoshita, S. Immunohistochemical Detection of Propionibacterium acnes in the Retinal Granulomas in Patients with Ocular Sarcoidosis. Sci. Rep. 2017, 7, 15226. [CrossRef]

54. Suzuki, T.; Fujita, A. Implication of Immunohistochemistry for Propionibacterium acnes in Differential Diagnosis of Necrotizing Granuloma. J. Pulm. Respir. Med. 2016, 6. [CrossRef]

55. Isshiki, T.; Matsuyama, H.; Sakamoto, S.; Honma, N.; Mikami, T.; Shibuya, K.; Eishi, Y.; Homma, S. Development of Propionibacterium acnes-associated Sarcoidosis During Etanercept Therapy. Intern. Med. 2019, 58, 1473-1477. [CrossRef]

56. Asahina, A.; Miura, K.; Saito, I.; Oshikata, C.; Ishii, N.; Eishi, Y. Cutaneous sarcoidosis with livedoid lesions: Evidence of the involvement of Propionibacterium acnes. J. Dermatol. 2013, 40, 501-502. [CrossRef] [PubMed] 
57. Takama, H.; Yanagishista, T.; Muto, J.; Ohshima, Y.; Takahashi, E.; Tsuzuki, T.; Uchida, K.; Eishi, Y.; Akiyama, M.; Watanabe, D. Granulomatous pigmented purpuric dermatosis containing Propionibacterium acnes. Eur. J. Dermatol. 2018, 28, 540-542. [CrossRef]

58. Noda, S.; Maeda, A.; Komiya, Y.; Soejima, M. A Patient with Necrotizing Vasculitis Related to Sarcoidosis, which Was Diagnosed via Immunohistochemical Methods Using Propionibacterium acnes-specific Monoclonal Antibodies. Intern. Med. 2020, 59, 2423-2425. [CrossRef] [PubMed]

59. Inoue, Y.; Teraki, Y. Association of Propionibacterium acnes with the efficacy of minocycline therapy for cutaneous sarcoidosis. Int. J. Dermatol. 2020, 59, 704-708. [CrossRef] [PubMed]

60. Takama, H.; Ohshima, Y.; Ando, Y.; Yanagishita, T.; Takahashi, E.; Tsuzuki, T.; Uchida, K.; Eishi, Y.; Akiyama, M.; Watanabe, D. Annular Sarcoidosis with Geographic Appearance in a Patient with Systemic Sarcoidosis. Acta Derm. Venereol. 2020, 100, adv00182. [CrossRef]

61. Sasaki, S.; Kato, M.; Nakamura, K.; Namba, Y.; Nagashima, O.; Takahashi, K. Management of skin sarcoidosis with minocycline monotherapy. Respirol. Case Rep. 2019, 7, e00413. [CrossRef]

62. Ishikawa, M.; Ohashi, T.; Eishi, Y.; Yamamoto, T. Palmoplantar pustulosis in a patient with sarcoidosis. Eur. J. Dermatol. 2020, 30, 325-326. [CrossRef]

63. Shimamura, S.; Yokogawa, N.; Murata, K.; Yamaguchi, T.; Uchida, K.; Eishi, Y. Saddle nose with sarcoidosis: A great imitator of relapsing polychondritis. Mod. Rheumatol. 2018, 28, 1053-1057. [CrossRef]

64. Yang, G.; Eishi, Y.; Raza, A.; Rojas, H.; Achiriloaie, A.; De Los Reyes, K.; Raghavan, R. Propionibacterium acnes-associated neurosarcoidosis: A case report with review of the literature. Neuropathology 2018, 38, 159-164. [CrossRef]

65. Akimoto, J.; Nagai, K.; Ogasawara, D.; Tanaka, Y.; Izawa, H.; Kohno, M.; Uchida, K.; Eishi, Y. Solitary tentorial sarcoid granuloma associated with Propionibacterium acnes infection: Case report. J. Neurosurg. 2017, 127, 687-690. [CrossRef] [PubMed]

66. Takemori, N.; Nakamura, M.; Kojima, M.; Eishi, Y. Successful treatment in a case of Propionibacterium acnes-associated sarcoidosis with clarithromycin administration: A case report. J. Med. Case Rep. 2014, 8, 15. [CrossRef] [PubMed]

67. Sawahata, M.; Fujiki, Y.; Nakano, N.; Ohtsuki, M.; Yamaguchi, T.; Uchida, K.; Eishi, Y.; Suzuki, T.; Hagiwara, K.; Bando, M. Propionibacterium acnes-associated Sarcoidosis Possibly Initially Triggered by Interferon-alpha Therapy. Intern. Med. 2020, 30. [CrossRef]

68. Sawahata, M.; Sakamoto, N.; Yamasawa, H.; Iijima, Y.; Kawata, H.; Yamaguchi, T.; Uchida, K.; Eishi, Y.; Bando, M.; Hagiwara, K. Propionibacterium acnes-associated sarcoidosis complicated by acute bird-related hypersensitivity pneumonitis. BMC Pulm. Med. 2020, 20. [CrossRef] [PubMed]

69. Moller, D.R. Potential etiologic agents in sarcoidosis. Proc. Am. Thorac. Soc. 2007, 4, 465-468. [CrossRef] [PubMed]

70. Chen, E.S.; Moller, D.R. Etiologies of Sarcoidosis. Clin. Rev. Allergy Immunol. 2015, 49, 6-18. [CrossRef]

71. Kinloch, A.J.; Kaiser, Y.; Wolfgeher, D.; Ai, J.; Eklund, A.; Clark, M.R.; Grunewald, J. In Situ Humoral Immunity to Vimentin in HLA-DRB1*03+ Patients with Pulmonary Sarcoidosis. Front. Immunol. 2018, 9, 1516. [CrossRef]

72. Thiboutot, D.M.; Layton, A.M.; Anne Eady, E. IL-17: A key player in the P. acnes inflammatory cascade? J. Investig. Dermatol. 2014, 134, 307-310. [CrossRef]

73. Kistowska, M.; Meier, B.; Proust, T.; Feldmeyer, L.; Cozzio, A.; Kuendig, T.; Contassot, E.; French, L.E. Propionibacterium acnes promotes Th17 and Th17/Th1 responses in acne patients. J. Investig. Dermatol. 2015, 135, 110-118. [CrossRef]

74. Calender, A.; Weichhart, T.; Valeyre, D.; Pacheco, Y. Current Insights in Genetics of Sarcoidosis: Functional and Clinical Impacts. J. Clin. Med. 2020, 9, 2633. [CrossRef] [PubMed]

75. Pacheco, Y.; Lim, C.X.; Weichhart, T.; Valeyre, D.; Bentaher, A.; Calender, A. Sarcoidosis and the mTOR, Rac1, and Autophagy Triad. Trends Immunol. 2020, 41, 286-299. [CrossRef]

76. Calender, A.; Lim, C.X.; Weichhart, T.; Buisson, A.; Besnard, V.; Rollat-Farnier, P.A.; Bardel, C.; Roy, P.; Cottin, V.; Devouassoux, G.; et al. Exome sequencing and pathogenicity-network analysis of five French families implicate mTOR signalling and autophagy in familial sarcoidosis. Eur. Respir. J. 2019, 54. [CrossRef] [PubMed]

77. Scharschmidt, T.C.; Vasquez, K.S.; Truong, H.-A.; Gearty, S.V.; Pauli, M.L.; Nosbaum, A.; Gratz, I.K.; Otto, M.; Moon, J.J.; Liese, J.; et al. A Wave of Regulatory T Cells into Neonatal Skin Mediates Tolerance to Commensal Microbes. Immunity 2015, 43, $1011-1021$. [CrossRef] [PubMed]

78. Senaldi, G.; Yin, S.; Shaklee, C.L.; Piguet, P.F.; Mak, T.W.; Ulich, T.R. Corynebacterium parvum- and Mycobacterium bovis bacillus Calmette-Guerin-induced granuloma formation is inhibited in TNF receptor I (TNF-RI) knockout mice and by treatment with soluble TNF-RI. J. Immunol. 1996, 157, 5022-5026.

79. Yamane, H.; Tachibana, I.; Takeda, Y.; Saito, Y.; Tamura, Y.; He, P.; Suzuki, M.; Shima, Y.; Yoneda, T.; Hoshino, S.; et al. Propionibacterium acnes-induced hepatic granuloma formation is impaired in mice lacking tetraspanin CD9. J. Pathol. 2005, 206, 486-492. [CrossRef]

80. Gabrilovich, M.I.; Walrath, J.; van Lunteren, J.; Nethery, D.; Seifu, M.; Kern, J.A.; Harding, C.V.; Tuscano, L.; Lee, H.; Williams, S.D.; et al. Disordered Toll-like receptor 2 responses in the pathogenesis of pulmonary sarcoidosis. Clin. Exp. Immunol. 2013, 173, 512-522. [CrossRef]

81. Werner, J.L.; Escolero, S.G.; Hewlett, J.T.; Mak, T.N.; Williams, B.P.; Eishi, Y.; Núñez, G. Induction of Pulmonary Granuloma Formation by Propionibacterium acnes Is Regulated by MyD88 and Nox2. Am. J. Respir. Cell Mol. Biol. 2017, 56, 121-130. [CrossRef] 
82. Nishiwaki, T.; Yoneyama, H.; Eishi, Y.; Matsuo, N.; Tatsumi, K.; Kimura, H.; Kuriyama, T.; Matsushima, K. Indigenous pulmonary Propionibacterium acnes primes the host in the development of sarcoid-like pulmonary granulomatosis in mice. Am. J. Pathol. 2004, 165, 631-639. [CrossRef]

83. Minami, J.; Eishi, Y.; Ishige, Y.; Kobayashi, I.; Ishige, I.; Kobayashi, D.; Ando, N.; Uchida, K.; Ikeda, S.; Sorimachi, N.; et al. Pulmonary granulomas caused experimentally in mice by a recombinant trigger-factor protein of Propionibacterium acnes. J. Med. Dent. Sci. 2003, 50, 265-274.

84. Suzuki, Y.; Uchida, K.; Takemura, T.; Sekine, M.; Tamura, T.; Furukawa, A.; Hebisawa, A.; Sakakibara, Y.; Awano, N.; Amano, T.; et al. Propionibacterium acnes-derived insoluble immune complexes in sinus macrophages of lymph nodes affected by sarcoidosis. PLoS ONE 2018, 13, e0192408. [CrossRef]

85. Yamada, Y.; Tatsumi, K.; Yamaguchi, T.; Tanabe, N.; Takiguchi, Y.; Kuriyama, T.; Mikami, R. Influence of stressful life events on the onset of sarcoidosis. Respirology 2003, 8, 186-191. [CrossRef] [PubMed]

86. Marin, M.; Harpaz, R.; Zhang, J.; Wollan, P.C.; Bialek, S.R.; Yawn, B.P. Risk Factors for Herpes Zoster Among Adults. Open Forum Infect. Dis. 2016, 3, ofw119. [CrossRef] [PubMed]

87. Keane, J. TNF-blocking agents and tuberculosis: New drugs illuminate an old topic. Rheumatology 2005, 44, 714-720. [CrossRef]

88. Chopra, A.; Nautiyal, A.; Kalkanis, A.; Judson, M.A. Drug-Induced Sarcoidosis-Like Reactions. Chest 2018, $154,664-677$. [CrossRef] [PubMed] 